\title{
ANALYSIS OF CAUSES That LED TO THE INSOLVENCY USING THE IC RATING ASSESSMENT METHOD
}

\section{RADNEANTU, N.; STAN, E. R. \& GABROVEANU E.}

Abstract: In an era where more and more businesses become insolvent or bankrupt the intellectual capital gain more and more importance because it is a driver of growth, innovation and profitability. A study conducted by the CITR in 2013 shows that the three main causes that led to insolvency of the organizations majority are indebtedness, management errors and consumption reducing. This paper presents the conclusions of a study on the causes that led to the insolvency of the Romanian companies and also check if the results of CITR study are correct. To increase the relevance we used IC Rating assessment methodology.

Key words: intellectual capital, insolvency, organizational capital, human capital, relational capital
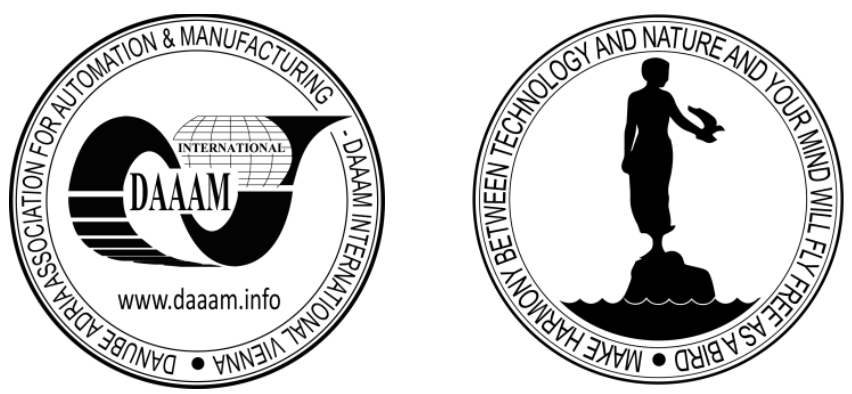

Authors' data: Teaching Assistant Dr. Radneantu N[icoleta]*; Lecturer Dr. Stan E[lena] R[oxana]**, Associate professor Dr. Gabroveanu E[milia]***, */**/**** Romanian-American University, 1B Expozitiei Blvd., Sector 1, code 012101, Bucharest - Romania, * CITR Group, Gara Herastrau Str, no 4, Sector 2, Bucharest, nicoleta.radneantu@yahoo.com,seroxana@gmail.com, emilia.gabroveanu@gmail.com

This Publication has to be referred as: Radneantu, N[icoleta]; Stan, E[lena] R[oxana] \& Gabroveanu, E[milia] (2015). Analysis of Causes That Led to the Insolvency Using the IC Rating Assessment Method, Chapter 26 in DAAAM International Scientific Book 2015, pp.311-318, B. Katalinic (Ed.), Published by DAAAM International, ISBN 978-3-902734-05-1, ISSN 1726-9687, Vienna, Austria DOI: $10.2507 /$ daaam.scibook.2015.26 
Radneantu, N.; Stan, E. R. \& Gabroveanu, E.: Analysis of Causes That Led to the I...

\section{Introduction}

The number of companies that became insolvent in the first 11 months of 2014 decreased by $27.35 \%$ to approximately 19,700 from over 27,000 in the same period last year, according to the National Trade Register Office (ONRC). Distributions on months and counties are shown in Figure no. 1 so we can see that the periods with fewer companies fall into disbursement incapacity are August (641) September (926) and October (1316), and counties with the largest decreases were Mehedinti (-76.31\%), Vaslui (-68.86\%) and Giurgiu (-65.9\%) compared to 2013 (http://www.mediafax.ro/economic/numarul-firmelor-intrate-in-insolventa-inprimele-11-luni-a-scazut-cu-27-35-13735524).

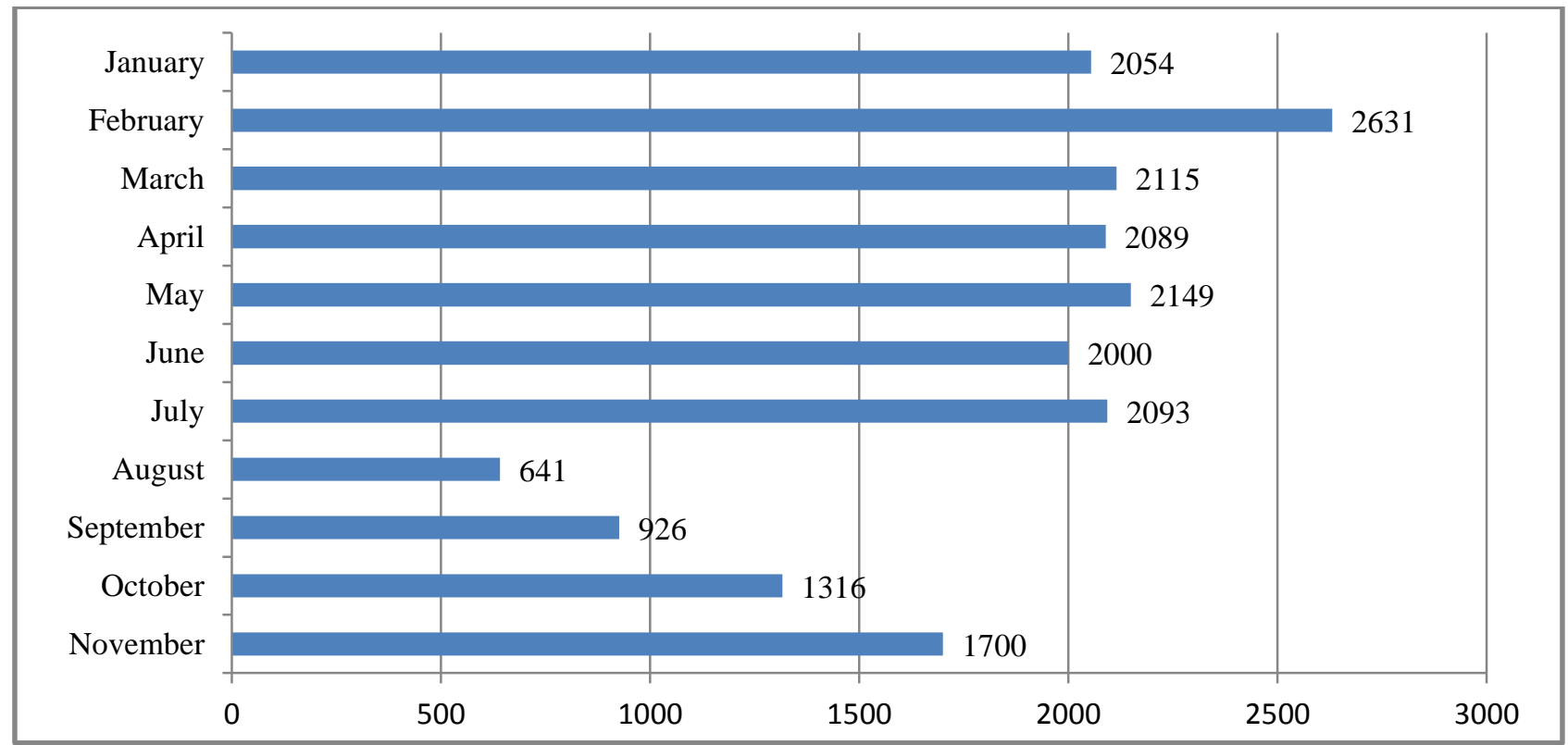

Fig. 1. Insolvent companies in 2014

However we cannot ignore the fact that the insolvent companies in 2014 generated losses of 9.4 billion lei. Companies that became insolvent in the first nine months of 2014 generated uncovered liabilities totalling 9.4 billion lei (2.1 billion. Euros), half of this amount is allocated for providers, and $40 \%$ returns to banks (http://www.zf.ro/zf24/firmele-intrate-in-insolventa-in-2014-au-generat-pierderi-de-9-4-miliarde-de-leiin-economie-anul-trecut-13542039).

\section{Identification and analysis of factors that generated insolvency}

A study conducted by the Transylvania Insolvency House in 2013 shows that the three main causes that led to insolvency of the organizations majority are indebtedness, management errors and consumption reducing. Other important causes are continued losses in the current activity, but also domino effects of some imbalances, where a company`s insolvency had direct impact on others (http://economie.hotnews.ro/stirifinante_banci-14985764-jumatate-din-companiile-romanesti-care-intra-insolventa- 
drept-cauza-supra-indatorarea-locul-doi-trei-motivelor-sunt-adjudecate-eorilemanagement-scaderea-consumului-studiu.htm).

To determine and remove the causes that led to insolvency of companies can be use a nonstandard analysis method, but successfully adopted internationally - IC Rating.

IC Rating Assessment Method (IC Rating, http://www.icrating.com) - assumes managing a simple framework to increase the organization competitiveness. This method can be (figure 2):

- basis for a modern business control system determining the objectives for maximizing future profitability;

- basis for improving and changing the activity, which can be used for both management and operational level. The indicator determines which areas need improvement and provides guidance on what should be done to reach the desired result. - an important perspective on the assets creative of future benefits than can be used by organization stakeholders (annual financial statements) and within organization.

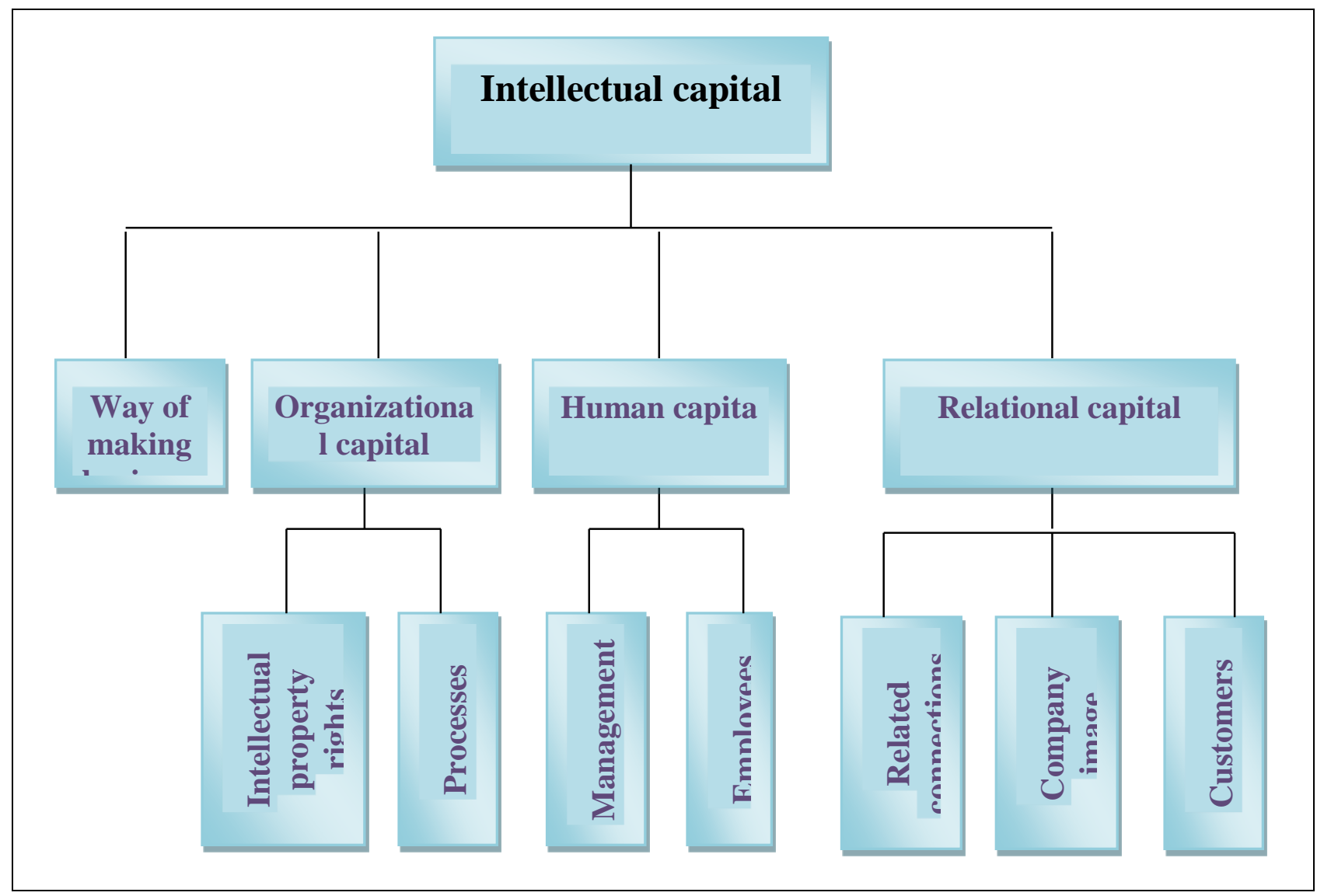

Fig. 2. Intellectual Capital Structure

Source: *** IC Rating, http://www.icrating.com

In table 1 are shown the main components of the intellectual capital elements (way of making business, intellectual property rights, processes, management, employees, related connections - networking, image - brand and customers), as they appear in calculating IC Rating indicator. 


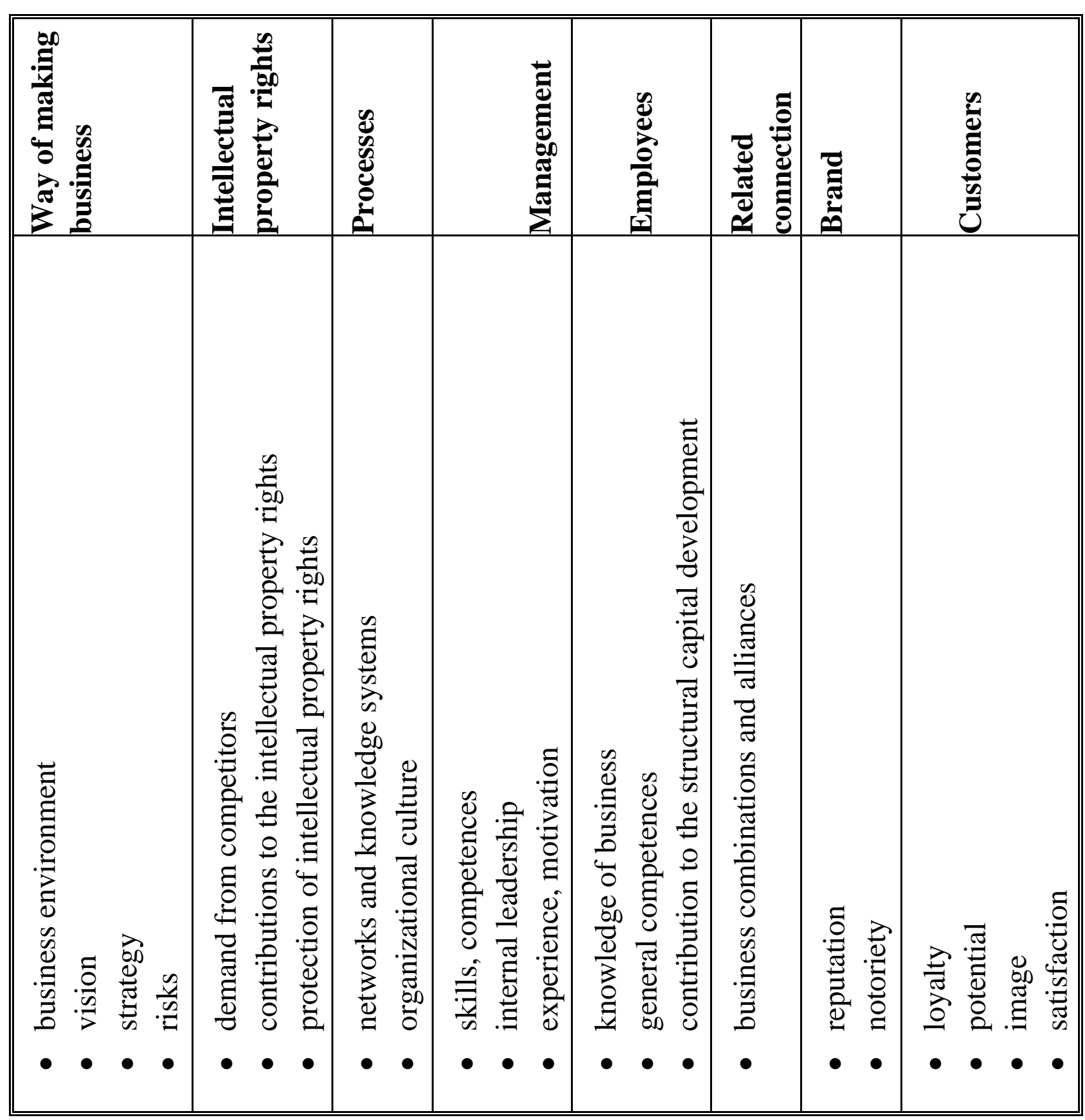

Tab. 1. Detailed structure of the intellectual capital elements

Source: *** Intellectual Capital Sweden, http://www.intellectualcapital.se/rating.htm

\section{Methodology used}

Compared to traditional assessment methods, IC Rating, besides determining the actual efficiency of the organization, it analyses the innovation and development efforts and skills, but also the risks that would lead to current efficiency reduction (HofmanBang P. \& Martin H, 2005).

Thus, the determination of:

- current efficiency shows which are the performances if the organization uses optimally the intangible assets;

- Risks leads to the identification of current threats, but also of future threats facing the organization. Regarding intellectual capital the model takes into account the 
situation where based employees would resign from the company. The risk is considered greater as the person that wants to resign has knowledge/experience that can be considered crucial for the organization;

- Innovation and development degree - in this case the model takes into account factors such as process innovation, new product development, employees training and development, etc.

Within IC Rating method are evaluated over 200 key intangible factors in determining performance. The main sources of information are the organization internal and external stakeholders.

The assessment results are presented on three levels:

- Executive level - examines three perspectives (effectiveness, risks that determine efficiency decreases and innovation). Based on questionnaires are obtained varying perception degrees for the three analysed levels, in which "AAA" is the highest level, and "D" is the lowest (Table no. 2).

- Operational level - provides additional details. IC Rating TM assessment method uses a presentation technique called polar diagram.

- Respondents level - is an additional detail of the operational level. This level is a written document in which respondents are classified according to the questions asked and the categories they belong. This is the moment when appear non-quantifiable knowledge.

\begin{tabular}{|c|c|c|}
\hline EFFICIENCY & INNOVATION & $\begin{array}{l}\text { RISK } \\
\end{array}$ \\
\hline $\begin{array}{l}\text { A A A - maximum level of } \\
\text { efficiency } \\
\text { A A - very high level of } \\
\text { efficiency } \\
\text { A - high level of efficiency } \\
\text { B B B - relatively high level of } \\
\text { efficiency } \\
\text { B B - average level of efficiency } \\
\text { B - relatively low level of } \\
\text { efficiency } \\
\text { C C C - low level of efficiency } \\
\text { C C - very low level of } \\
\text { efficiency } \\
\text { C - extremely low level of } \\
\text { efficiency } \\
\text { D - inefficiency }\end{array}$ & $\begin{array}{l}\text { A A A - maximum level of } \\
\text { innovation } \\
\text { A A - very high level of } \\
\text { innovation } \\
\text { A - high level of innovation } \\
\text { B B B - relatively high level } \\
\text { of innovation } \\
\text { B B - average level of } \\
\text { innovation } \\
\text { B - relatively low level of } \\
\text { innovation } \\
\text { C C C - low level of } \\
\text { innovation } \\
\text { C C - very low level of } \\
\text { innovation } \\
\text { C - extremely low level of } \\
\text { innovation } \\
\text { D - lack of innovation }\end{array}$ & $\begin{array}{l}\text { - - negligible risk } \\
\text { of decline } \\
\mathrm{R} \text { - moderate level } \\
\text { of risk } \\
\mathrm{RR} \text { - high level of } \\
\text { risk } \\
\text { RRR - very high } \\
\text { level of risk }\end{array}$ \\
\hline
\end{tabular}

Tab. 2. IC Rating - perceptiveness

Source: *** IC Rating, http://www.icrating.com 
We used for illustration company Alfa. Alfa is a company producing clothing.

Executive level analysis is detailed as follows:

$\rightarrow$ figure 3 shows the company efficiency analysis;

$\rightarrow$ figure 4 presents the risks facing the company;

$\rightarrow$ figure 5 shows the company innovation degree.

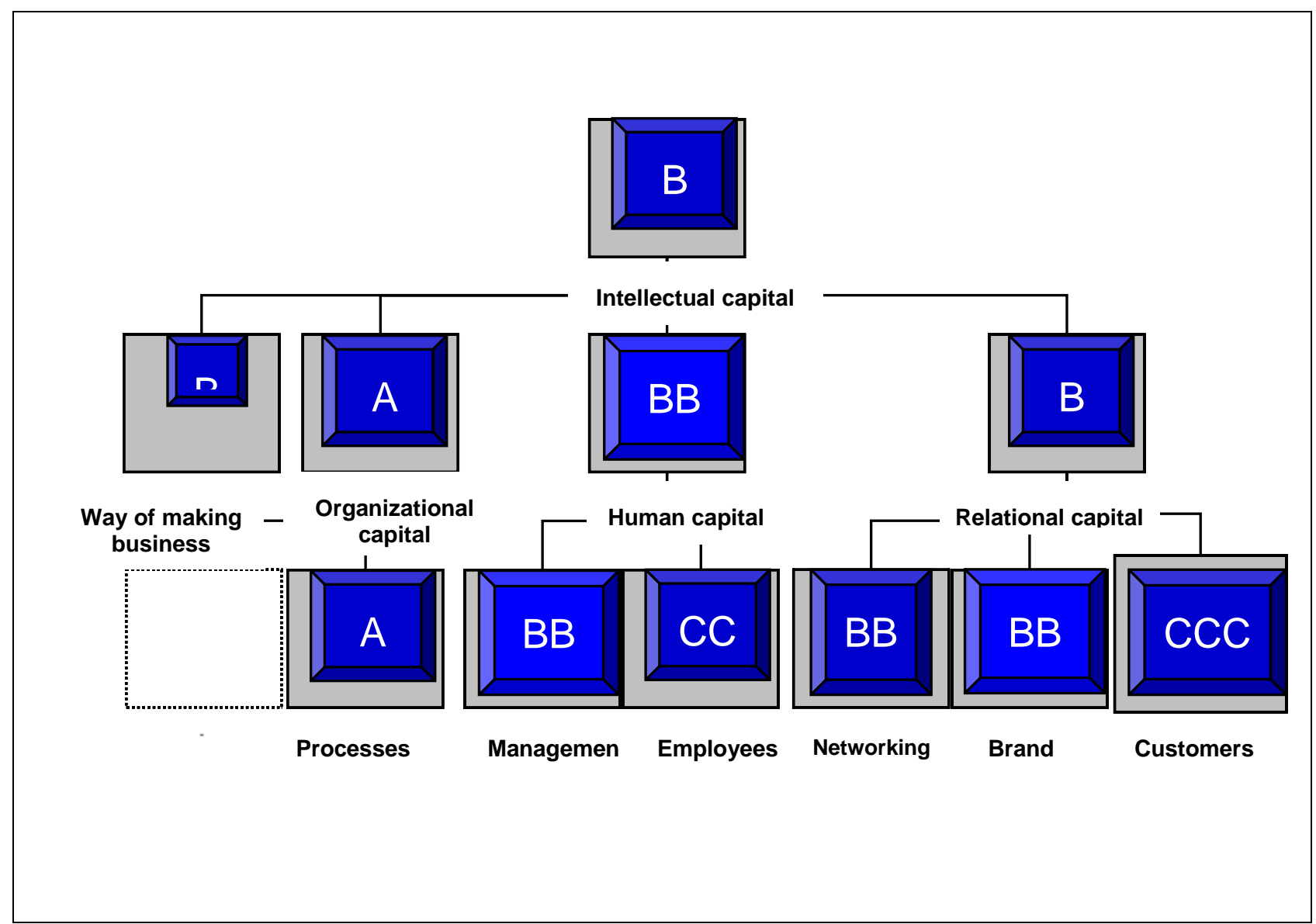

Fig. 3. Efficiency analysis using IC Rating assessment model

Looking at figure 3 we see that the company Alfa shows an average level of efficiency which is confirmed by the fact that it is known one of the best clothing producers. The main factors that have average level of efficiency are notoriety, company reputation, brand, customers and management.

Looking at figure 4, we note that the overall level of risk is high. Very high levels have customers and employees.

The emergence of the risk of employees is explained by the large number of employees - about 20000 employees who manufacture products in more than 20 factories located in 15 countries around the world. We can see that if the company's based employees would resign the company could face major problems (RRR - high level of risk) because those people have both knowledge and experience that can be considered crucial for the organization. Given that internationally there is a fierce competition in the clothing manufacture we can believe that the risk related to economic environment, but also the one regarding the company recognition are normal in a free market. 


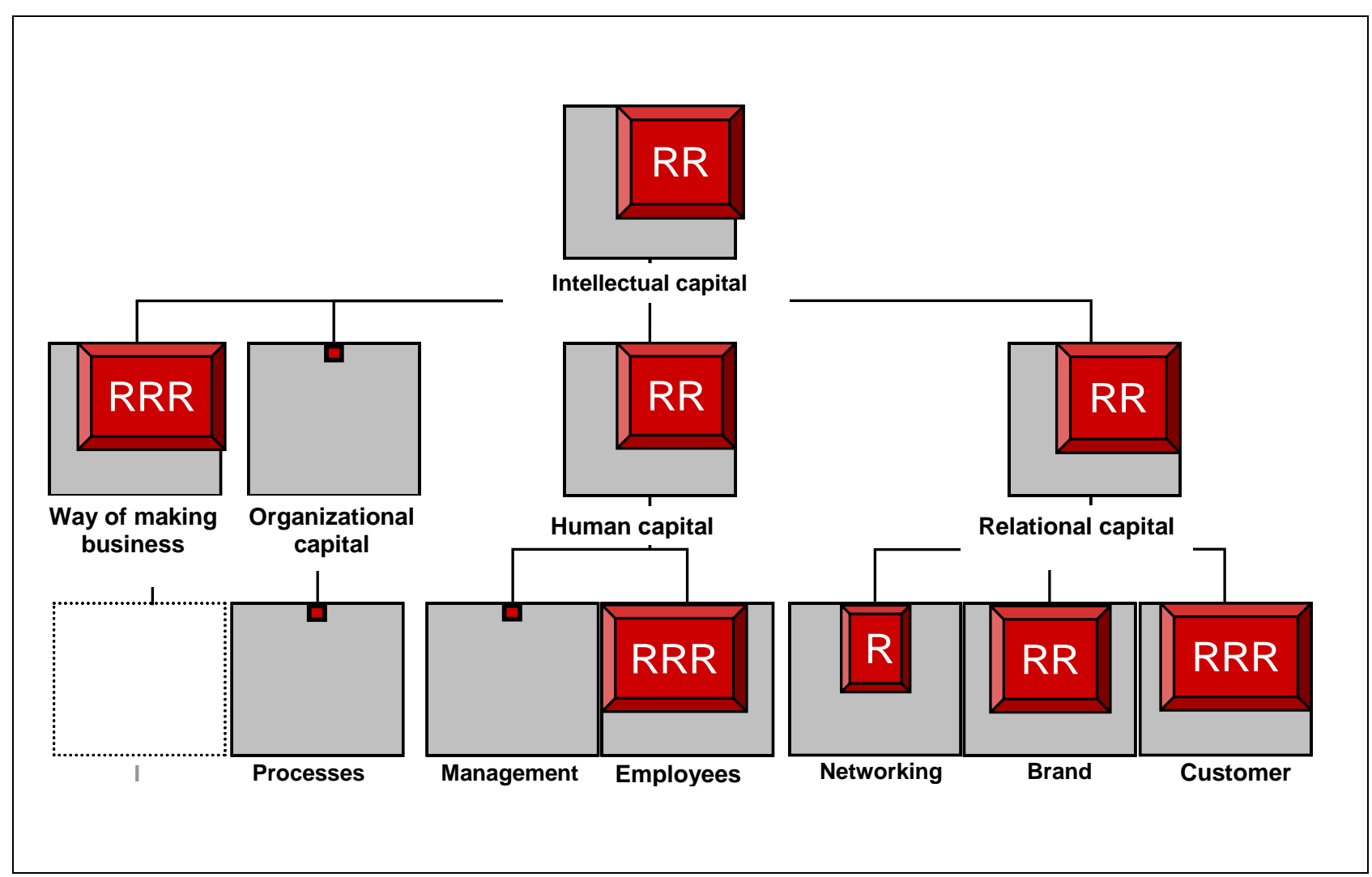

Fig. 4. Risk analysis using IC Rating assessment model

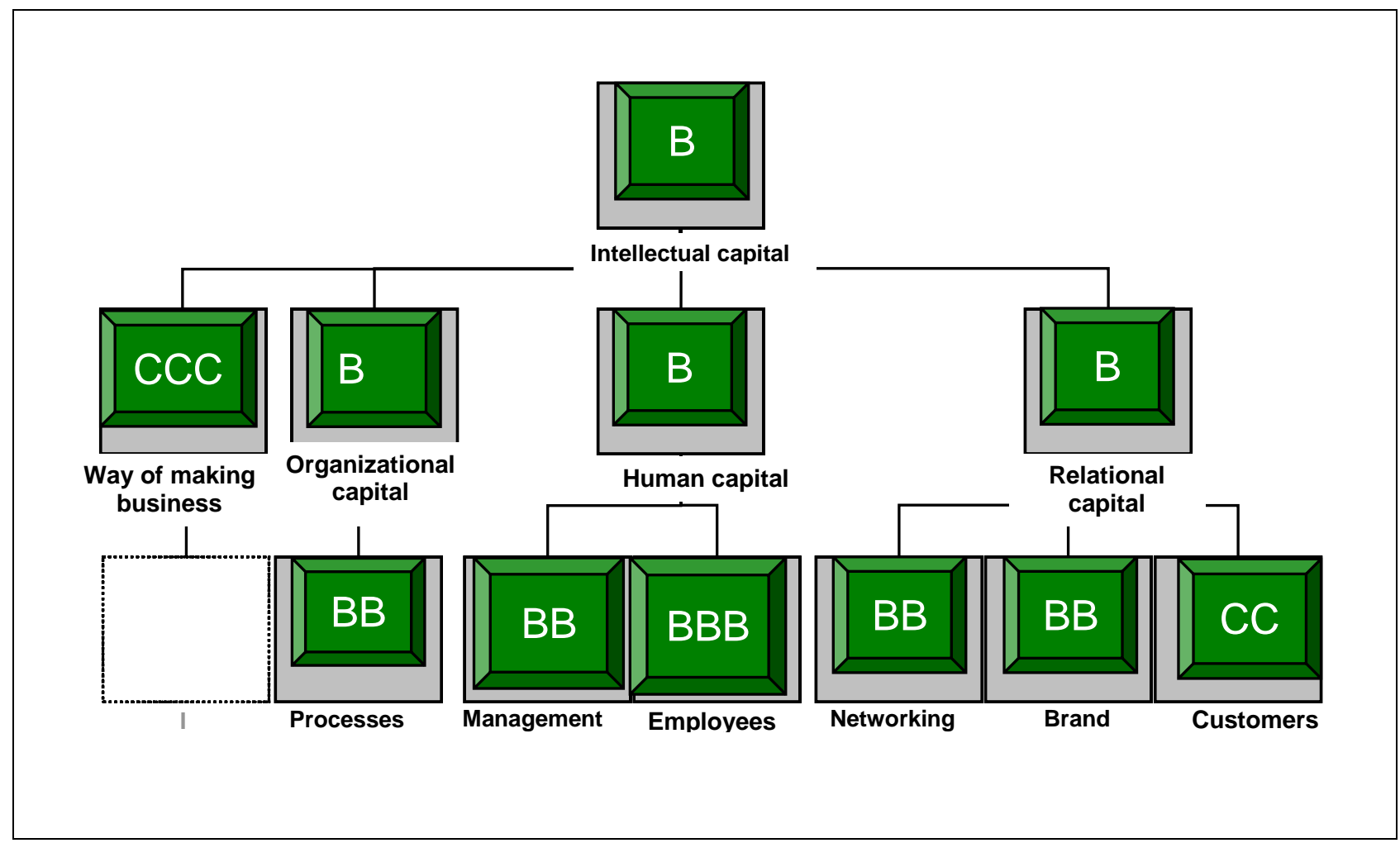

Fig. 5. Innovation analysis using IC Rating assessment model

As seen from figure no. 5 Alfa has a low level of innovation. The main factors that led to this level of innovation are: management, employees, networking, brand, networks and knowledge systems and organizational culture. 
Radneantu, N.; Stan, E. R. \& Gabroveanu, E.: Analysis of Causes That Led to the I...

\section{Conclusion}

In conclusion the research carried out shows that using IC Rating method for assessing the causes which led to the insolvency of the company Alfa has resulted in increased transparency, improved staff capacity of interpretation on growth of nonfinancial factors and determined areas with problems (relationships with employees and customers, way of making business, management) in order to develop new plans or strategies to increase efficiency, reduce risks and increase the level of innovation.

As we state in the abstract, comparing the result of the study made by CITR in 2013 with the result of IC Rating Methodology we can observe that results are almost the same. So, IC Rating can be successfully used to determine the actual efficiency of the organization, the innovation and development efforts and skills, the risks that would lead to current efficiency reduction not only in insolvent organisation, but in every organisation.

\section{References}

Adams M., Oleksak M, 2010, Intangible Capital. Putting Knowledge to Work in the 21st - Century Organization, Praeger, Santa Barbara, California

Hofman-Bang P. \& Martin H. (2005), IC Rating, E-mentor, nr. 4 (11), available on: www.e-mentor.edu.pl.eng

Intellectual Capital Sweden, http://www.intellectualcapital.se/rating.htm

IC Rating, http://www.icrating.com

Marr B , 2008, Impacting Future Value: How to Manage your Intellectual Capital, http://media.journalofaccountancy.com/JOA/Issues/2008/09/MAG\%20IntCapitalEng.pdf

Marr B., (c), 2008, Making the Invisible Visible: Identifying the Enablers of Future Value., Journal of Accountancy, vol. 206

Sveiby K. E., 2007, updated 2010 , Methods for Measuring Intangible Assets, disponibil la: http://www.sveiby.com/Portals/0/articles/IntangibleMethods.htm

Shepard E., 2000, Transforming knowledge into professional power. Association Management, 52(13), 16.

***http://www.mediafax.ro/economic/numarul-firmelor-intrate-in-insolventa-inprimele-11-luni-a-scazut-cu-27-35-13735524

***http://www.zf.ro/zf-24/firmele-intrate-in-insolventa-in-2014-au-generat-pierderide-9-4-miliarde-de-lei-in-economie-anul-trecut-13542039

***http://economie.hotnews.ro/stiri-finante_banci-14985764-jumatate-dincompaniile-romanesti-care-intra-insolventa-drept-cauza-supra-indatorarea-locul-doitrei-motivelor-sunt-adjudecate-eorile-management-scaderea-consumului-studiu.htm 